\title{
Achievement of Clinical Learning Outcomes and Associated Factors Among Midwifery and Nursing Undergraduate Students of Jimma University, Ethiopia
}

\author{
Kebenesa Angasu (D) \\ Tariku Bekela \\ School of Midwifery, Faculty of Health \\ Sciences, Institute of Health, Jimma \\ University, Jimma, Ethiopia
}

Background: Effective achievement of clinical learning outcomes indicates the success of the clinically oriented educational program including midwifery and nursing. In contrast, studies reported poor achievement of clinical competence in different health sciences programs in the country. Thus, this study aimed to determine the status of achievement of clinical learning outcomes and associated factors among midwifery and nursing students of Jimma University, Ethiopia.

Methods: Institution-based cross-sectional study was conducted from March 25 to 30, 2021 among 147 midwifery and nursing students of Jimma University selected by simple random sampling technique. Data were collected by a semi-structured, pre-tested, self-administered questionnaire, entered into EpiData version 4.2, and analyzed by SPSS version 23. Bivariate and multivariable logistic regression analyses were done to test the association. The odds ratio at $95 \%$ confidence interval $(\mathrm{CI})$ and $\mathrm{P}$-value $<0.05$ was used to ascertain statistical significance.

Results: Only 65 (44.2\%) participants achieved their clinical learning outcomes. Being a third year student (AOR 3.38; 95\% CI $=1.5,7.5$ ) at $\mathrm{p}$-value $=0.003$, having good practice of COVID-19 preventive measures (AOR 2.25; 95\% CI $=1.01,5)$ at $\mathrm{p}$-value $=0.047$, perceived high students load in clinical teaching site (AOR $4.9 ; 95 \% \mathrm{CI}=1.6,14.7)$ at $\mathrm{p}$-value $=0.005$, and students motivation to their clinical learning $(\mathrm{AOR} 3.1 ; 95 \% \mathrm{CI}=1.4$, $6.63)$ at $\mathrm{p}$-value $=0.004$ were factors positively associated with achievement of clinical learning outcomes.

Conclusion: Less than half of midwifery and nursing students of Jimma University had achieved their clinical learning outcomes. Therefore, the students, clinical teachers, and all concerned bodies should struggle their best to enhance good practice of COVID-19 preventive measures, students motivation to their clinical learning, and facilitate clinical learning in clinical teaching site with high students load for better achievement of clinical learning outcomes.

Keywords: achievement, clinical learning outcomes, midwifery, nursing, Jimma University

\section{Introduction}

Authentic clinical education is the essential part of midwifery and nursing education. ${ }^{1,2}$ Theoretical training can simply be gained from relevant text book, lecture note, and classroom or video teaching. ${ }^{3}$ But successful clinical education needs placement in health facility with enough caseload, clear learning objectives, optimal guidance, motivation, and timely frequent feedback with subsequent adequate practice opportunity. ${ }^{1,3}$ For ensuring successful clinical learning; the students
Correspondence: Kebenesa Angasu Tel +251919841766

Email kebenesa2019@gmail.com 
preparedness and commitment, and their teachers' attitude, competencies and positive relationship with students to make them feel welcomed and motivated is mandatory. ${ }^{4}$

Similar to the case in foreign countries, clinical practice training for both undergraduate midwifery and nursing program continues from second year to fourth year starting with basic skills to advanced procedures. ${ }^{5}$ It is during clinical education that midwifery and nursing students learn what midwifery and nursing really means by gaining the ability to integrate vital cognitive, affective, and psychomotor skills essential for delivering effective care. ${ }^{2,6-8}$ But midwives or nurses who lacked effective clinical education provide ineffective care with serious harmful consequences on patients' safety. ${ }^{1}$

Due to lockdown measures taken by Ethiopian national government to reduce transmission of Coronavirus disease (COVID-19), students of Jimma University (JU) stayed away from the university for eight months. ${ }^{9,10}$ Because of the education time expired during the lockdown, currently midwifery and nursing students of JU are learning their subject matter within very limited time to finish a semester within only two months that normally take four months. This means that clinical learning time is reduced by half of its preplanned time on their curriculum. ${ }^{10}$ In contrast, Ethiopia has urgent need for qualified health work force both in midwifery and nursing. 11

Shortening time of clinical practice from the preplanned leads to gradual reduction in students' clinical competence and students' ability to develop relationship with patients, attendants, and clinical staffs. ${ }^{12,13}$ Compounding this, there is high competition of learners in clinical area between students from different departments that further diminish their chance of maximum use of their clinical learning time exactly on practicing nurse/ midwifery care process for better achievement of their clinical learning objectives. ${ }^{14}$

Previous study done among graduating diploma health extension students in Amhara region health sciences colleges in northern Ethiopia revealed that only 31.7\% passed national competency assessment. ${ }^{15}$ Similarly, $31.6 \%$ of midwifery graduates from different Ethiopian universities passed standard for graduation that indicates a great gap between the country's demand for competent health workforce and effectiveness of their clinical education. ${ }^{16}$ In addition, only $24.5 \%$ of 3 rd and 4 th year nursing students of Mettu University in western Ethiopia achieved their clinical learning outcomes while year of study and conduciveness of clinical placement predicted positively. ${ }^{17}$

Factors facilitating clinical learning included: clinical practice opportunity, adequate caseload, strict and continuous guidance by clinical teachers, small group of students per clinical units, immediate feedback, supportive clients and staff, and students' motivation. ${ }^{18,19}$ Offering preclinical orientation, distributing and clarifying clinical learning outcome also contributes to better clinical learning. ${ }^{20}$

Overall, previous studies done in the country revealed poor achievement of clinical competency among different health science departments. ${ }^{15-17}$ But the achievement of clinical learning outcomes is the determinant of the overall success of both nursing and midwifery educational programs. ${ }^{21}$ Thus, this study aimed to determine the status of achievement of clinical learning outcomes and associated factors among midwifery and nursing students of Jimma University after resumption of educational program following lockdown for COVID-19. The findings of this study contribute new knowledge on the topic and helps concerned bodies to make necessary measurement to improve the achievement of clinical competence among midwifery and nursing students thereby contributing to production of qualified health work force to satisfy the country's demand.

\section{Methods}

\section{Study Design and Period}

An institution-based quantitative cross-sectional study was conducted from March 25 to 30, 2021.

\section{Study Setting}

This study was conducted in a School of Midwifery and a School of Nursing of JU. JU is well known and among the oldest universities in Ethiopia. It is found in Jimma town of Oromia region at a distance of 356 kilometers to southwest of Addis Ababa, the capital city of the country. By the time this study was conducted, there were 236 undergraduate students in the School of Midwifery (93 students) and School of Nursing (143 students) of JU learning third and fourth year. Students of both schools had their clinical practice recently after lockdown for COVID-19 in Jimma University Medical Center where there are high load of students from different schools such as medicine, pharmacy, public health officer, and anesthesia. 


\section{Source Population}

All regular undergraduate third and fourth-year midwifery and nursing students of JU were the source population.

\section{Study Population}

Sampled regular undergraduate third and fourth-year midwifery and nursing students of JU were the study population.

\section{Inclusion and Exclusion Criteria}

All regular undergraduate third and fourth-year midwifery and nursing students of JU who were available in the campus at the time of the data collection period were included in the study. Students who were taking re-exam at the time of the data collection period were excluded by considering the focus by which they respond may be deprived and students who had a severe illness during the data collection period were excluded.

\section{Sample Size Determination and Sampling Technique}

Since the source population for this study was small, the formula $\left(n=\left(N z^{2} p(1-p) / E^{2}(N-1)+z^{2} p(1-p)\right)\right)$ for normal approximation to the hyper-geometric distribution was used. Where: $\mathrm{n}$ is required sample size; $\mathrm{N}$ is population size thus, $236 ; \mathrm{z}$ is the critical value at $95 \%$ confidence level, thus 1.96; $\mathrm{p}$ is proportion of midwifery and nursing students who achieved their clinical learning outcome were taken as $50 \%$ due to lack of relevant previous study and for gaining relatively larger sample size; $\mathrm{E}$ is level of precision taken as $5 \%$ resulting. Thus, $\mathrm{n}=$ $236 * 1.96^{2 *} 0.5 * 0.5 / 0.05^{2}(236-1)+1.96^{2 *} 0.5 * 0.5 ; \quad \mathrm{n}=$ 226.65/1.548; resulting in 147 final sample size. The sample size was proportionally allocated for third and fourthyear midwifery and nursing students. Finally, a simple random sampling technique was used to select study participants.

\section{Data Collection Instrument and Pre-Test}

A pre-tested, semi-structured questionnaire developed after reviewing relevant literature was used to collect data. ${ }^{3,5,12,14,17}$ The questionnaire contains four sections: socio-demographic characteristics (nine questions), practice of COVID-19 preventive measures (seven questions), perceived impact of COVID-19 on clinical practice (three questions), and achievement of clinical learning outcomes (twelve questions). The questionnaire was developed in
English and was not translated to local language as respondents were university students and they were considered as they understand English as it is the official language at the university level in the country. The pretest was done on $15(10 \%)$ of the sample size among nursing students of Rift valley University Jimma campus before the actual study. After the pre-test, the questionnaire was amended regarding its clarity, understandability, and completeness.

\section{Operational Definition}

Practicing COVID-19 preventive measures: was measured using seven items responded by "yes" or "no" while correct response coded " 1 " and incorrect coded " 0 ". The responses summed up and respondents who responded always practiced four or more (above half) of the preventive measures were considered as having good practice of COVID-19 preventive measures and those who practiced three or less were considered as having a poor practice of COVID-19 preventive measures.

Achievement of clinical learning outcomes: it is the actual state of acquiring clinical learning competencies preplanned on the curriculum to the desired level.

Achievement of clinical learning outcomes scale: it was measured by students' own perception of achieving their clinical learning outcomes using twelve items directed on five areas of clinical learning process. As such, eight questions were focused on assessment part that included ability of taking patient history, performing physical examination, prescribing and interpreting laboratory investigations. The remaining four questions were focused on acquiring ability to make appropriate diagnosis, planning, intervention, and evaluation. Each question was responded as "yes" or "no" and correct answer coded " 1 " and incorrect coded "0". The total score summed up making maximum "12" and minimum " 0 ". As a result, respondents who scored $\geq 7.2(60 \%)$ were considered as achieved their clinical learning outcomes and those who scored below sixty percent were considered as not achieved their clinical learning outcomes. Sixty percent was taken as cut-point as it is cut point of clinical competency by the curriculum of undergraduate midwifery program in Ethiopian public universities.

\section{Data Collection Method}

Data were collected by self-administered questionnaire when students were in their usual classroom after communicating with their classroom teachers. Data collection was 
facilitated by four data collectors (BSc. nurses) and two supervisors (MSc. nurses) who were trained on data collection tools and methods of data collection for one-day duration. At the beginning, data collectors had introduced the title and objectives of the study, its benefit, absence of risk, how to respond, confidentiality of their response, and the time it takes for responding to the questions briefly and informed written consent taken. Any unclear points were described throughout and filled questionnaires were handed to data collectors just after it was responded to. The supervisors had facilitated the schedule of data collection and checked completeness of filled questionnaires.

\section{Data Quality Control}

Data quality assured before, during and after data collection. Before data collection, the questionnaire was pre-tested and training given for data collectors and supervisors. During data collection, the objective of the study and strict assurance of confidentiality of responses were clarified for participants to encourage them to provide their genuine response. After data collection, filled questionnaires were checked for completeness, coded, and entered into EpiData version 4.2.

\section{Data Analysis}

Data entered into EpiData version 4.2 were exported to SPSS version 23 for analysis. Bivariate analysis was done to test the crude association of predictors with the achievement of clinical learning outcomes. Variables with p-value less than 0.25 on bivariate analysis were included in multivariable logistic regression analysis. The odds ratio at $95 \%$ Confidence Interval (CI) was used to measure the statistical association. P-values less than 0.05 were used to determine the statistical significance. Finally, the results were presented by table and text.

\section{Ethical Consideration}

This study was conducted as per the Declaration of Helsinki. Ethical approval was obtained from the institutional review board of Jimma University Institute of Health. A formal letter was obtained from the school of midwifery of JU. Each study participant was informed about the purpose, benefit, risk, confidentiality of their response, and written informed consent was obtained. Participants were granted to refuse to respond to the question they wanted and their right to withdraw at any point.

\section{Results}

\section{Socio-Demographic Characteristics of Respondents}

In this study, 147 regular undergraduate midwifery and nursing students participated and the response rate was $100 \%$. Just more than half, $81(55.1 \%)$, of respondents were female. The median age was 22 years while the range was between 20 and 30 years. The majority, 135 $(91.7 \%)$, of respondents were single. Three-fifths, 89 (60.5\%), of respondents were nursing students and just more than half, 77 (52.4\%), of respondents were fourth year students. Nearly two-fifths, 57 (38.8), of respondents were Orthodox while 48 (32.7\%), and 36 (24.5\%), were Protestant and Muslim religion followers respectively. The rest six were Wakefata, Adventist, and Apostolic (Table 1).

\section{Practice of COVID-19 Preventive Measures}

Overall, nearly two-thirds, 93 (63.3\%), of respondents had good practice of COVID-19 preventive measures. Just more than half, 78 (53.1\%), of respondents frequently cleaned their hands either by soap and water or alcoholbased hand rub. Eighty (54.4\%) respondents always maintained a two-meter distance from any person who sneezed and coughed. Seventy-nine (53.7\%) respondents wore a face mask always when it was impossible to maintain a two-meter physical distance. Slightly more than threefifths, 92 (62.6\%), of participants always avoided touching eyes, nose, and mouth with unclean hands. Nearly threefourths, $110(74.8 \%)$, of respondents always sneezed and coughed into a bent elbow. Around two-thirds, 99 (67.3\%), and seven-tenths, $103(70.1 \%)$, of respondents reported

Table I Socio-Demographic Characteristics of Regular Undergraduate Midwifery and Nursing Students of Jimma University, Southwest Ethiopia, 202I, $(n=147)$

\begin{tabular}{|l|l|l|l|}
\hline Variables & Category & Frequency & Percent (\%) \\
\hline Sex & Female & 81 & 55.1 \\
& Male & 66 & 44.9 \\
\hline School & Midwifery & 58 & 39.5 \\
& Nursing & 89 & 60.5 \\
\hline \multirow{2}{*}{ Study year } & Third year & 70 & 47.6 \\
& Fourth year & 77 & 52.4 \\
\hline \multirow{2}{*}{ Residence } & Urban & 93 & 63.3 \\
& Rural & 54 & 36.7 \\
\hline
\end{tabular}


that they stayed home when they felt unwell and sought medical care when they experienced serious symptoms of COVID-19 (Table 2).

\section{Perceived Impact of COVID-19 on Clinical Learning}

A higher proportion, 112 (76.2\%), of respondents perceived that there was a high student load in clinical learning sites due to overlap of clinical practice of different health departments as a result of congested time due to COVID-19. Nearly two-thirdsc 95 (64.6\%), of respondents perceived that the clinical learning time was shortened. Just more than half, 78 (53.1\%), of respondents responded that they were not motivated to their clinical learning due to being in the era of COVID-19.

Table 2 Practice of COVID-19 Preventive Measures Among Regular Undergraduate Midwifery and Nursing Students of Jimma University, South West Ethiopia, 202I, $(n=147)$

\begin{tabular}{|c|c|c|c|}
\hline Variables & Category & Frequency & Percent (\%) \\
\hline $\begin{array}{l}\text { Always frequently } \\
\text { cleaned hands }\end{array}$ & $\begin{array}{l}\text { Yes } \\
\text { No }\end{array}$ & $\begin{array}{l}78 \\
69\end{array}$ & $\begin{array}{l}53.1 \\
46.9\end{array}$ \\
\hline $\begin{array}{l}\text { Always maintained two } \\
\text { meter distance from } \\
\text { anyone who sneezed } \\
\text { and coughed }\end{array}$ & $\begin{array}{l}\text { Yes } \\
\text { No }\end{array}$ & $\begin{array}{l}80 \\
67\end{array}$ & $\begin{array}{l}54.4 \\
45.6\end{array}$ \\
\hline $\begin{array}{l}\text { Always wore face mask } \\
\text { when physical } \\
\text { distancing is impossible }\end{array}$ & $\begin{array}{l}\text { Yes } \\
\text { No }\end{array}$ & $\begin{array}{l}79 \\
68\end{array}$ & $\begin{array}{l}53.7 \\
46.3\end{array}$ \\
\hline $\begin{array}{l}\text { Always avoided touching } \\
\text { eyes, nose and mouth } \\
\text { before cleaning hands }\end{array}$ & $\begin{array}{l}\text { Yes } \\
\text { No }\end{array}$ & $\begin{array}{l}92 \\
55\end{array}$ & $\begin{array}{l}62.6 \\
37.4\end{array}$ \\
\hline $\begin{array}{l}\text { Always sneezed or } \\
\text { coughed into a bent } \\
\text { elbow }\end{array}$ & $\begin{array}{l}\text { Yes } \\
\text { No }\end{array}$ & $\begin{array}{l}110 \\
37\end{array}$ & $\begin{array}{l}74.8 \\
25.2\end{array}$ \\
\hline $\begin{array}{l}\text { Always stayed home } \\
\text { when felt unwell }\end{array}$ & $\begin{array}{l}\text { Yes } \\
\text { No }\end{array}$ & $\begin{array}{l}99 \\
48\end{array}$ & $\begin{array}{l}67.3 \\
32.7\end{array}$ \\
\hline $\begin{array}{l}\text { Always sought medical } \\
\text { care when experienced } \\
\text { serious symptom of } \\
\text { Covid-19 }\end{array}$ & $\begin{array}{l}\text { Yes } \\
\text { No }\end{array}$ & $\begin{array}{l}103 \\
44\end{array}$ & $\begin{array}{l}70.1 \\
29.9\end{array}$ \\
\hline $\begin{array}{l}\text { Overall practice of } \\
\text { COVID-19 preventive } \\
\text { measures }\end{array}$ & $\begin{array}{l}\text { Good } \\
\text { Poor }\end{array}$ & $\begin{array}{l}93 \\
54\end{array}$ & $\begin{array}{l}63.3 \\
36.7\end{array}$ \\
\hline
\end{tabular}

\section{Achievement of Clinical Learning} Outcomes and Factors Associated with It

Less than half, 65 (44.2\%), of respondents perceived that they achieved their clinical learning outcomes during their clinical practicum after lockdown for COVID-19 (Table 3). Out of six variables associated with the outcome variable in

Table 3 Perceived Achievement of Clinical Learning Outcomes Among Regular Undergraduate Midwifery and Nursing Students of Jimma University, South West Ethiopia, 202I, $(n=147)$

\begin{tabular}{|c|c|c|c|}
\hline Variables & Category & Frequency & Percent (\%) \\
\hline $\begin{array}{l}\text { Abled taking patients' } \\
\text { chief compliant correctly }\end{array}$ & $\begin{array}{l}\text { Yes } \\
\text { No }\end{array}$ & $\begin{array}{l}88 \\
59\end{array}$ & $\begin{array}{l}59.9 \\
40.1\end{array}$ \\
\hline $\begin{array}{l}\text { Abled taking patients' } \\
\text { history of present illness } \\
\text { correctly }\end{array}$ & $\begin{array}{l}\text { Yes } \\
\text { No }\end{array}$ & $\begin{array}{l}81 \\
66\end{array}$ & $\begin{array}{l}55.1 \\
44.9\end{array}$ \\
\hline $\begin{array}{l}\text { Abled taking patients' } \\
\text { past history of illness } \\
\text { correctly }\end{array}$ & $\begin{array}{l}\text { Yes } \\
\text { No }\end{array}$ & $\begin{array}{l}83 \\
64\end{array}$ & $\begin{array}{l}56.5 \\
43.5\end{array}$ \\
\hline $\begin{array}{l}\text { Abled measuring all } \\
\text { patients' vital signs } \\
\text { correctly }\end{array}$ & $\begin{array}{l}\text { Yes } \\
\text { No }\end{array}$ & $\begin{array}{l}82 \\
65\end{array}$ & $\begin{array}{l}55.8 \\
44.2\end{array}$ \\
\hline $\begin{array}{l}\text { Abled performing } \\
\text { patients' general physical } \\
\text { examination correctly }\end{array}$ & $\begin{array}{l}\text { Yes } \\
\text { No }\end{array}$ & $\begin{array}{l}70 \\
77\end{array}$ & $\begin{array}{l}47.6 \\
52.4\end{array}$ \\
\hline $\begin{array}{l}\text { Abled characterizing } \\
\text { relevant patient physical } \\
\text { finding correctly }\end{array}$ & $\begin{array}{l}\text { Yes } \\
\text { No }\end{array}$ & $\begin{array}{l}67 \\
80\end{array}$ & $\begin{array}{l}45.6 \\
54.4\end{array}$ \\
\hline $\begin{array}{l}\text { Abled prescribing } \\
\text { appropriate laboratory } \\
\text { examination }\end{array}$ & $\begin{array}{l}\text { Yes } \\
\text { No }\end{array}$ & $\begin{array}{l}63 \\
84\end{array}$ & $\begin{array}{l}42.9 \\
57.1\end{array}$ \\
\hline $\begin{array}{l}\text { Abled interpreting } \\
\text { laboratory results } \\
\text { correctly }\end{array}$ & $\begin{array}{l}\text { Yes } \\
\text { No }\end{array}$ & $\begin{array}{l}68 \\
79\end{array}$ & $\begin{array}{l}46.3 \\
53.7\end{array}$ \\
\hline $\begin{array}{l}\text { Abled diagnosing patient } \\
\text { problem correctly }\end{array}$ & $\begin{array}{l}\text { Yes } \\
\text { No }\end{array}$ & $\begin{array}{l}74 \\
73\end{array}$ & $\begin{array}{l}50.3 \\
49.7\end{array}$ \\
\hline $\begin{array}{l}\text { Abled developing } \\
\text { appropriate patient care } \\
\text { plan }\end{array}$ & $\begin{array}{l}\text { Yes } \\
\text { No }\end{array}$ & $\begin{array}{l}74 \\
73\end{array}$ & $\begin{array}{l}50.3 \\
49.7\end{array}$ \\
\hline $\begin{array}{l}\text { Abled implementing } \\
\text { patients' care plan } \\
\text { correctly }\end{array}$ & $\begin{array}{l}\text { Yes } \\
\text { No }\end{array}$ & $\begin{array}{l}74 \\
73\end{array}$ & $\begin{array}{l}50.3 \\
49.7\end{array}$ \\
\hline $\begin{array}{l}\text { Abled evaluating patients' } \\
\text { progress after your } \\
\text { intervention }\end{array}$ & $\begin{array}{l}\text { Yes } \\
\text { No }\end{array}$ & $\begin{array}{l}79 \\
68\end{array}$ & $\begin{array}{l}53.7 \\
46.3\end{array}$ \\
\hline $\begin{array}{l}\text { Overall achievement of } \\
\text { Clinical learning outcomes }\end{array}$ & $\begin{array}{l}\text { Achieved } \\
\text { Not achieved }\end{array}$ & $\begin{array}{l}65 \\
82\end{array}$ & $\begin{array}{l}44.2 \\
55.8\end{array}$ \\
\hline
\end{tabular}


bivariate logistic regression at $\mathrm{p}$-value $<0.25$, four variables were statistically significantly associated with the outcome variable in multivariable logistic regression. These variables are: year of study, practice of COVID-19 preventive measures, perceived students load in clinical learning area, and students' motivation to clinical learning.

The odds of achieving clinical learning outcomes among third year midwifery and nursing students was 3.38 times higher compared to the fourth year students (AOR 3.38; 95\% CI $=1.5,7.5)$ at $\mathrm{p}$-value $=0.003$. The odds of achieving clinical learning outcomes among midwifery and nursing students who had good practice of COVID-19 preventive measures was 2.25 times higher than midwifery and nursing students who had poor practice of COVID-19 preventive measures (AOR 2.25; 95\% $\mathrm{CI}=1.01,5)$ at $\mathrm{p}$-value $=0.047$.

Similarly, the odds of achieving clinical learning outcomes was 4.9 times higher among midwifery and nursing students who perceived high load of students in clinical learning site compared to their counterparts (AOR 4.9; $95 \% \mathrm{CI}=1.6,14.7)$ at $\mathrm{p}$-value $=0.005$. Finally, the odds of achieving clinical learning outcomes among midwifery and nursing students who were motivated to their clinical learning was 3.1 times higher compared to midwifery and nursing students who were not motivated to their clinical learning $(\mathrm{AOR} 3.1 ; 95 \% \mathrm{CI}=1.4,6.63)$ at $\mathrm{p}$-value $=0.004$ (Table 4).

\section{Discussion}

This study found that less than half, 65 (44.2\%), of midwifery and nursing regular undergraduate students of Jimma University had achieved their clinical learning outcomes after education program resumed following lockdown for COVID-19. The factors associated with achievement of clinical learning outcomes were: year of study, practice of COVID-19 preventive measures, perceived students' load in clinical learning sites, and students' motivation to their clinical learning. These results are based on students' self-assessment score. Students' self-assessment induces their thinking about their own learning and inspires metacognitive skills that deepen their learning. Thus, student self-assessment is a key for motivating students and leading to best achievement. ${ }^{22}$

The finding of the current study is higher than the finding of a study done in Mettu University where only $24.5 \%$ of third and fourth year nursing students reported achieved their clinical competence. ${ }^{17}$ The possible reason for the discrepancy may be due to the difference in the status of the universities as the current study is done in old and best recognized university in the country while Mettu University is comparatively new university that may lack adequate experienced and competent faculties than Jimma University. On the other hand, since less than half of the current study participants had achieved their clinical learning outcomes, it implies that much effort should be

Table 4 Bivariate and Multivariable Analysis of Factors Associated with Achievement of Clinical Learning Outcome Among Regular Undergraduate Midwifery and Nursing Students of Jimma University, Southwest Ethiopia, 202I, $(n=147)$

\begin{tabular}{|c|c|c|c|c|c|c|}
\hline \multirow[t]{2}{*}{ Variables } & \multirow[t]{2}{*}{ Category } & \multicolumn{2}{|c|}{ Achieved Clinical Learning Outcome } & \multirow[t]{2}{*}{ COR $(95 \% \mathrm{Cl})$} & \multirow[t]{2}{*}{ AOR $(95 \% \mathrm{Cl})$} & \multirow[t]{2}{*}{ P-value } \\
\hline & & Yes (N, \%) & No (N, \%) & & & \\
\hline School & $\begin{array}{l}\text { Midwifery } \\
\text { Nursing }\end{array}$ & $\begin{array}{l}21(36.2) \\
44(49.4)\end{array}$ & $\begin{array}{l}37(63.8) \\
45(50.6)\end{array}$ & $\begin{array}{l}0.58(0.3,1.14) \\
I\end{array}$ & $\begin{array}{l}0.6(0.27,1.33) \\
\mathrm{I}\end{array}$ & 0.208 \\
\hline Year of study & $\begin{array}{l}\text { Third } \\
\text { Fourth }\end{array}$ & $\begin{array}{l}42(60) \\
23(29.9)\end{array}$ & $\begin{array}{l}28(40) \\
54(70.1)\end{array}$ & $\begin{array}{l}3.52(1.78,7) \\
\text { I }\end{array}$ & $\begin{array}{l}3.38(1.5,7.5) \\
\text { I }\end{array}$ & $0.003^{*}$ \\
\hline Practice of COVID-19 PM & $\begin{array}{l}\text { Good } \\
\text { Poor }\end{array}$ & $\begin{array}{l}49(52.7) \\
16(29.6)\end{array}$ & $\begin{array}{l}44(47.3) \\
38(70.4)\end{array}$ & $\begin{array}{l}2.64(1.3,5.4) \\
1\end{array}$ & $\begin{array}{l}2.25(1.01,5) \\
1\end{array}$ & $0.047^{*}$ \\
\hline Perceived students load & $\begin{array}{l}\text { High } \\
\text { Low }\end{array}$ & $\begin{array}{l}54(48.2) \\
\mathrm{II}(3 \mathrm{I} .4)\end{array}$ & $\begin{array}{l}58(51.8) \\
24(68.6)\end{array}$ & $\begin{array}{l}2.03(0.9,4.5) \\
\text { I }\end{array}$ & $\begin{array}{l}4.9(1.6,14.7) \\
\text { I }\end{array}$ & $0.005^{*}$ \\
\hline Perceived duration of $\mathrm{CL}$ & $\begin{array}{l}\text { Shortened } \\
\text { Enough }\end{array}$ & $\begin{array}{l}39(41.1) \\
26(50)\end{array}$ & $\begin{array}{l}56(58.9) \\
26(50)\end{array}$ & $\begin{array}{l}0.7(0.4,1.4) \\
\text { I }\end{array}$ & $\begin{array}{l}0.49(0.19,1.27) \\
\text { । }\end{array}$ & 0.143 \\
\hline Students' motivation to $\mathrm{CL}$ & $\begin{array}{l}\text { Motivated } \\
\text { Not motivated }\end{array}$ & $\begin{array}{l}43(62.3) \\
22(28.2)\end{array}$ & $\begin{array}{l}26(37.7) \\
56(71.8)\end{array}$ & $\begin{array}{l}4.2(2.1,8.4) \\
1\end{array}$ & $\begin{array}{l}3.1(1.4,6.63) \\
\text { I }\end{array}$ & $0.004 *$ \\
\hline
\end{tabular}

Note: *Indicate statistical significance at $\mathrm{p}$-value less than 0.05 .

Abbreviations: COR, crudes odds ratio; AOR, adjusted odds ratio; PM, preventive measures; CL, clinical learning. 
undertaken by students, their clinical teachers, and all other stake holders to further improve the clinical learning achievement of students that will lead into production of competent demand driven health work force.

Year of study was found to be associated positively with achievement of clinical learning outcomes while being third year predicted more achievement of clinical learning outcomes. But according to study done in Mettu University, being fourth year student predicted better clinical learning outcomes. ${ }^{17}$ The possible reason for the discrepancy may be due to the difference in students' estimation of their clinical learning outcomes achievement and may also be due to the difference in the competency of clinical teacher each year of study had that they may or may not perceive as enabling them to achieve their clinical learning outcomes.

In addition, having good practice of COVID-19 preventive measure is positively associated with achievement of clinical learning outcomes. But there was no previous published study on the association between achievement of clinical learning outcomes and good practice of COVID-19 preventive measures. The positive association can be explained by the fact that more competent students have good self-esteem, care for themselves, and also better achieve their clinical learning outcomes.

Moreover, perceived high load of students in clinical learning area was positively associated with achievement of clinical learning outcomes. This is not in line with studies done in public universities of Ethiopia where 5 to 8 students per clinical unit were found to be associated with better achievement of clinical learning competency. ${ }^{14}$ The possible reason for the discrepancy may be due to the current study participants best management of high students load in clinical unit. This may include using high students' load as best opportunity for better peer learning and better experience sharing with each other.

Lastly, students' motivation to their clinical learning was associated with better achievement of clinical learning outcomes in the current study. This is in line with the findings of a qualitative study done in Kuwait where student's motivation was indicated as a factor that facilitates better achievement of clinical learning outcomes. ${ }^{19}$ Also, it is in line with the result of a study done in Ankara where learner motivation resulted in best performance oriented learning. ${ }^{23}$ This can be supported with the general fact that learner's motivation is a necessary condition for learning.

\section{Strengths and Limitation}

This study was done in one of the leading universities in the country. So that the university itself will use the findings to better improve the achievement of clinical learning of its students. Other new universities in the country can also take lessons from the experience of this university and better improve their students' achievement of clinical learning outcomes. As this study is based on students' selfassessment, we believe that it also served as formative assessment to improve our study participant's learning. To minimize information bias, we used a pre-tested questionnaire and trained data collectors and supervisors. Data quality was maintained throughout the study by using software for data entry (EpiData, v.4.2) and analysis (SPSS v.23). However, it was not without limitation. It was better to incorporate teachers' evaluation of each student's achievement of clinical learning outcomes to enhance the accuracy of the estimation.

\section{Conclusion}

Even though the status of achieving clinical learning outcomes revealed by self-assessment among midwifery and nursing students of JU is better than achievement of students from other universities and colleges in the country, still less than half of them achieved their clinical learning outcomes. Four factors were statistically significantly associated with achievement of clinical learning outcomes. Those factors were being third year student, having good practice of COVID-19 preventive measures, perceived high load of students in clinical teaching sites, and students' motivation towards their clinical learning. Thus, midwifery and nursing students of JU, their clinical educators and all concerned bodies should struggle their best to further improve achievement of clinical learning outcomes by promoting good practice of COVID-19 preventive measures, and students' motivation. Also, they should facilitate better way of strengthening clinical learning in the presence of high students' load.

\section{Abbreviations}

CI, Confidence Interval; COVID-19, Corona Virus Disease-2019; JU, Jimma University.

\section{Acknowledgments}

We are grateful to our data collectors and supervisors. We are also very thankful to our study participants for their willingness to participate in this study. 


\section{Author Contributions}

Both authors made a significant contribution to the work reported throughout starting from the conception of the research idea, study design, execution, acquisition of data, analysis, and interpretation, or in all these areas; took part in drafting, revising, or critically reviewing the article; gave final approval of the version to be published; have agreed on the journal to which the article has been submitted; and agree to be accountable for all aspects of the work.

\section{Disclosure}

The authors declare that they have no competing interests in this work.

\section{References}

1. Kobekyaa FK, Markhosizana BD, Bagrmwin L, et al. Current issues and challenges of clinical education in nursing and midwifery in Africa: protocol of a scoping review study. Nurs Primary Care. 2019;3(2):1-5.

2. Mrunalini M, Chandekar PA. Factors affecting the teaching-learning in nursing education. Am Res J Nurs. 2015;1(4).

3. Gaberson K, Oermann M, Shellenbarger T. Clinical teaching strategies in nursing [Internet]. New York: Springer publishing company; 2015. Available from: https://www.vitalsource.com/pro ducts/clinical-teaching-strategies-in-nursing-fifth-marilyn-h-oer mann-phd-rn-v9780826140036?_cf_chl_captcha_tk_=pmd_ XERIvN_7OyYXtkVhELDOfmNhVFFlw. 1 Y 8 H6e.g 1 n HJu 81629987922-0-gqNtZGzNAyWjenBszQZ1 . Accessed April 5, 2019.

4. Dale B, Leland A, Dale JG. What factors facilitate good learning experiences in clinical studies in nursing: bachelor students' perceptions. Int Sch Res Notices. 2013;2013:7. Hindawi Publishing Corporation. doi:10.1155/2013/628679

5. Ilankoon M, Kisokanth G, Warnakulasuriya S. COVID-19: impact on undergraduate nursing education in Sri Lanka. $J$ Public Health Res. 2020;9(s1):1916. doi:10.4081/jphr.2020.1916

6. Sezer H. How should clinical education be in nursing education? J Nurs Res Pract. 2018;2(1):15.

7. Baker K. Senior nursing students perception of clinical teacher behavior. Nursing Theses and Capstone Projects [Internet]; 2012:95. Available from: https://digitalcommons.gardner-webb.edu/nursing etd/95. Accessed March 17, 2019.

8. Anarado AN, Agu GU, Nwonu EI. Factors hindering clinical training of students in selected nursing educational institutions in Southeastern Nigeria. Nurse Educ Today. 2016;40:140-145. doi:10.1016/j.nedt.2016.02.022

9. COVID-19 pandemic in Ethiopia. Wikipedia. COVID-19 pandemic in Ethiopia - Wikipedia. Accessed February 26, 2021. Available from: https://en.wikipedia.org/wiki/COVID-19_pandemic_in_Ethiopia.

Accessed February 27, 2021.
10. Elias G. University World News Africa edition Ethiopia 22 October, 2020. Classes to resume soon for final-years at state universities. Available from: https://www.universityworldnews.com/post.php? story $=20201021203025367$. Accessed February 27, 2021.

11. Ethiopian Federal ministry of health human resource management. The need for midwife and nurse professionals. Available from: www. moh.gov.et. Accessed March 16, 2021.

12. Sani I, Hamza Y, Chedid Y, Amalendran J, Hamza N. Understanding the consequence of COVID-19 on undergraduate medical education: medical students' perspective. Ann Med Surg. 2020;58:117-119. doi:10.1016/j.amsu.2020.08.045

13. Ferrel MN, Ryan JJ. Impact of COVID -19 on medical education. Cureus. 2020;12(3). Open Access Editorial. doi:10.7759/cureus.7492

14. Angasu Kitaba K, Weldemariam S, Belachew AB, Bekela $\mathrm{T}$. Effective clinical teaching practice and associated factors among midwifery educators in public universities of Ethiopia: institution-based cross-sectional study. Adv Med Educ Pract. 2021;12:421-429. doi:10.2147/AMEP.S300049

15. Kassa AM, Bogale GG. Academic achievements in national competence assessment among health extension students in regional health science colleges, Amhara Region, Ethiopia. Adv Med Educ Pract. 2020;11:833-841. doi:10.2147/AMEP.S275182

16. Yigzaw T, Ayalew F, Kim Y, et al. How well does pre-service education prepare midwives for practice: competence assessment of midwifery students at the point of graduation in Ethiopia. BMC Med Educ. 2015;15(130):1-10. doi:10.1186/s12909-015-0410-6

17. Amsalu B, Fekadu T, Mengesha A, Bayana E. Clinical practice competence of mettu university nursing students: a cross-sectional study. Adv Med Educ Pract. 2020;11:791-798. doi:10.2147/AMEP. S267398

18. Fikre R. Assessment of factors affecting clinical practice competency of undergraduate health science students in Hawassa University, South, Ethiopia. Ann Clin Lab Res. 2016;4:1. doi:10.21767/23865180.100057

19. Shokria A, Chitra V, Manal A, Nabil A. A qualitative study on factors affecting the clinical learning of nursing students in college of nursing, Kuwait. J Educ Pract. 2017;8(36):141-155.

20. Gemuhay HM, Kalolo A, Mirisho R, Chipwaza B, Nyangena E. Factors affecting performance in clinical practice among preservice diploma nursing students in Northern Tanzania. J Nurs Res Pract. 2019;2019. doi:10.1155/2019/3453085

21. Dube MB, Mlotshwa PR. Factors influencing enrolled nursing students' academic performance at a selected private nursing education institution in KwaZulu-Natal. Curationis. 2018;41(1):a1850. doi:10. 4102/curationis.v41i1.1850

22. Edward F. Gehringer, North Carolina State University. Self-Assessment to Improve Learning and Evaluation. American Society for Engineering Education. Paper ID \#19411; 2017.

23. Funda N. The relationship between student motivation and class engagement levels. Eurasian J Educ Res. 2017;71:59-78.
Advances in Medical Education and Practice

\section{Publish your work in this journal}

Advances in Medical Education and Practice is an international, peerreviewed, open access journal that aims to present and publish research on Medical Education covering medical, dental, nursing and allied health care professional education. The journal covers undergraduate education, postgraduate training and continuing medical education including emerging trends and innovative models linking education, research, and health care services. The manuscript management system is completely online and includes a very quick and fair peer-review system. Visit http://www.dovepress.com/testimonials.php to read real quotes from published authors. 